\title{
The anomalous legal thought in building an equitable legal theory
}

\author{
Prof. I Made Arya Utama \\ Udayana University Faculty Of Law \\ Email:prof_imautama@yahoo.co.id
}

ARTICLE INFO

Article history:

Received, July 05, 2017

Revised, September 20, 2017

Accepted, November 232017

Keywords:

Anomalies

Justice

Legal Theory

Postmodern

\section{ABSTRACT}

The challenges of current and future Law Theories are not solely derived from within the Law itself, but also from the external about the law's enforceability in society. Therefore, the legal theories are currently experiencing anomalies. Legal Theory currently faced with the need to be able to bring about justice, certainty, order, and the benefits of protecting human rights as well as the sustainability of living creatures and the environment.

The method applied in this article is the normative legal research method with the source of legal material from the legislation and related literature. Library study became the technique of collecting the legal material and qualitative analysis applied to the legal material which has been described to produce the conclusion of the problems studied in this article.

The legal theory undergoes a shift following the perspective of legal scholars from classical times, modern times, and postmodern thinkers. The Depelovment Law Theory and Progressive Law Theory that grew up in the Postmodern era seeks to free the minds of the status quo, adopt legal ideas that are in line with the needs of the Indonesian people and the state that is moving in the crossroads of modernization. Laws are required to promote conscience implemented through legal products established by competent authorities, just laws, and laws protecting people and the environment.

Copyright () 2017 Indonesia Prime. All rights reserved.

\section{Introduction}

\section{Background}

World current laws in Indonesia in particular and the world, in General, is experiencing a considerable challenge. The challenge is not solely born from within the science of the law itself, but also from external associated with the enforceability of the law in the community. Theories of law are currently undergoing a period of "anomaly" towards a model of Legal Theory that can meet the needs of Justice, protection of the rights of human rights as well as the sustainability of the life of living beings in the world through environmental protection. Meanwhile externally, the existence of the law as an instrument of establishing fairness, certainty, and order the life of the community doubted its existence as a result of the behaviour of a combining apparatus and law enforcement.

The equitable legal phenomenon is not rare in the process of implementation and law enforcement in Indonesia. It republished by the verdict of the judiciary, consisting of the law remain however factually challenged. Law in Indonesia impressed only apply in the middle to bottom, circles and not fanged for among the 
public. For example, real burglary Sandals flops, burglary, theft of cocoa banana and other small cases, with very small nominal, yet still got the punishment. Meanwhile, corruption, misuse of finances of the State or the people's money, which resulted in the country harmed billion rupiahs, rarely touched by the law. Similarly, the existence of a plurality of justices of the judiciary as a stronghold of justice the mandate given by the Almighty God to create justice and order in this world have been fall in the mud of collusion, corruption, and Nepotism. A plurality of judges in various courts both on Public courts, Supreme Court, even the Constitutional Court has been the cause of distrust society to the existence of the judiciary. Many acts of "anarchist" in the judicial process we often see in process judiciary. The normative perception of legalism, such as qualification harassment action of the judiciary (contempt of court), while it was pragmatism that occurs as a result of the Act the person judge who allegedly did not uphold the truth and justice. As a result, the essence of the law questionable and debated in all walks of life. Despite the explain the law realized that it is not easy so far has not found a perfect sense. The difficulties it experienced from the Roman era to the present since, so there is no uniformity among legal experts or scholars about what is legal. It is shown by the pessimism that Immanuel Kant stated that "suchen Noch eine definition juristen die zu ihren begriffe von recht," the jurists are still looking for a definition of the notion of law. Similarly, Paul Scholten argued that the law could not formulate in a sentence. But to be able to understand it, at least there are four sentences that should be known, namely: recht is the bevel (the law is a command), recht is verlof (law is approval), recht is belofte (law was a promise), and dispositie (recht is the law provided).

\section{Formulation Of The Problem}

Opposite of the above, then the assessment against the existence of the law in the human dimensions of the life of society, nation, and State to be an interesting thing to do. Through the study of the legal position can be conceived in the era of anti-establishment and alternative solutions. Thus, as for the title of this article is an anomaly of the legal Thought in building Equitable Legal Theory.

\section{Research Methods}

The methods applied in the writing of these articles is a normative juridical method of moving on from the existence of the anomaly of the current Legal Theory thinking. About the source of the material law of the research based on laws and regulations and their related literature in the field of Legal Theory. The study of librarianship became his legal materials collection techniques and qualitative analysis applied against legal materials that have been described to produce conclusions that examined in this article.

\section{DISCUSSION}

\section{Legal concepts in the development of the theory of law}

Cicerio suggests that humans are social beings or sentient society (zoon politicon). Therefore, humans from birth in fact doomed to live together with other human beings. In the meantime, it is not supernatural is not the same man, who was born a twin, so the distinction of being the essence of human life. The consequences of human difference, then the conflict between human beings both in individual and/or a very difficult group avoided in the Association of human life. In this case, then the existence of the law with strict sanctions can become strategic institutions in organizing human relationships in the life of society, nation, and State. In other words, the law became essential for human life. The law will be found and/or necessary in any society on Earth, either primitive or modern society. Therefore, the existence of the law become universal and inseparable from the community.

About natural law, thinking has its characteristics (sui generis) which not found in ways of thinking to another. The flow of thought of law cannot release from the norms of logic that the underlying disease, i.e., the norms to think well and true. Likewise, the truth strongly 
influenced by the time and place of a thought the law was born. For example, the thinking patterns of flow law of nature that classified as "Legal Theory" with characters such as Plato, Aristotle, Montesquieu, Thomas Aquinas, Grotius (Hugo de Groot). Looked at the law applies universally, timeless, and it is not supernatural. In this case, the law is seen in force continuously since his relationship with nature. The law never changed, never disappear and apply by itself. Therefore, the law in this period is distinguished by positive law entirely depending on the conditions of man.

Aristotle distinguishes between natural law with positive law and States that the law must adhere to for the sake of Justice, good justice as a virtue of justice as General or specific moral virtue. Justice determines how good relationships between fellow human beings. Montesquieu provides an understanding of the law that is most definitely the public, i.e. relationship stems from the nature of all things. In this case, it understood all their laws have existed, including God, material world, animals, plants, and the man himself.

Thomas Aquinas Thomas Aquinas viewed the natural law is the Lord leads a law born of human reason on its activities. In that regard, he gave the law as "quendam rationis ordinatio ad bonum commune, ab eo communitatis habet promulgata, steep," i.e., commands that make sense, that are intended for the general welfare, created by those who undertake the task a society and dipromulgasikan or enacted. All-natural events in the world, in fact, ruled and controlled by an eternal law (lex eterna), i.e. the will and mind of the Lord that is the basis of power for all other regulations. The man gave God's ability to be able to tell which is good and bad as well as recognize various forms of legislation including the lex eterna contains principles such as doing good and Shun evil, act according to the mind healthy, love your neighbour as you love yourself.

In the age of enlightenment (Renaissance) with the progress of human thought, the thought of the law also experienced an anomaly that gave rise to the existence of the theories of Modern Law with his characters such as Jean Bodin, Hugo de Groot (Grotius), Hans Kelsen, John Austin. The era of the Renaissance, this is also influenced by the metaphysical cosmology. They recognized the existence of natural laws but not giving him as a major concern. For philosophers of this period, the law positive (human-made) that became the focus of attention. A positive theory of law as one of growing legal thinking of the time argued that the law was seen as the sovereign ruler command (John Austin) or is the will rather than the country (Hans Kelsen). Meanwhile, Hugo de Groot, searching humanism as the base of the enforceability of the law of nature in man himself. Humans are seen as having the ability to understand all things rationally through his thinking according to the laws of mathematics that can generally be accepted. The laws of nature by Grotius is seen as applicable law in real the same as positive law because of human minds as part of his essence. However, Grotius also recognized that God is the creator of the universe so that indirectly the Lord remains a fundament natural law.

Legal positivism, in this case, is trying to answer the legal issues through the system-a system of norms, the rules that apply so that the appropriate normative thinking legisme. John Austin contended that the law contains a command, obligation, sovereignty, and sanctions. In theory, known as analytical jurisprudence (the analytical theory of law), there are two known forms of law, namely positive law (legislation) and positive morality (i.e., the law of habit). Thought Jean Bodin influenced him through the concept of souverignity (sovereignty), the flow of legisme who think the only legal source of the formyl is legislation, as well as view the presence of willed Thibout codification of Justinian and Roman Code Napoleon. According to Jean Bodin, the power of the King was the supreme power over the citizens and the people. Law does not bind King himself (summa in cires ac legibusque subditos solute potestas), because the King was seen as the personification of the State so that if the King were under the law, then it would destroy the basic meaning of sovereignty 
(which one, round, and superior). Next on the Postmodern era (post Modern theory of law), the legal thoughts on the deconstruction with giving birth to the revolutionary movements against the establishment legal concepts like Critical Legal Studies, Feminist Jurisprudence, Semiotics Jurisprudence. Deconstruction in the law is a reversal strategy to help try to understand the hidden meanings in the concept. Associated with the method of deconstruction, Balkin explains that there are three interesting things in the deconstruction of the law. First, these techniques provide methodologies/how to do deep critic about the doctrines of the law. Second, deconstruction can explain how different legal arguments-arguments with ideology. Third, offering new interpretations of the text of the law. Feminist law experts with his characters such as Scales, McCann, Smart, and critically examines the law MacKinnon assuming essential the law has some limitations to the realization of social values, and the lawregarded very more phallocentris are favoring the interests of men. Feminist analysts braced their preconceived notions to the category "destruction," opposed to the presence of naturalistic, excessive generalizations, abstract and assumptions about the social world. View of feminism in law also rejected how women always marginalized in the legal relationship even though the women have been trying to improve his future but overshadowed by the more masculine ideology. Meanwhile, his characters with such jurisprudence the semiotics of Charles Sanders Pierce, Jacques Lacan tried blending analysis analysis of semiotics and the analysis of the law. The semiotics of law affected by the two great thoughts in semiotics, namely the European tradition is more noticed on structural analysis, semantic, and non-referential, as well as the American tradition rooted in pragmatism and non-referential.

\section{The thought of legal experts in Indonesia Struggle Anomaly theory of law}

Law thinking of legal experts in Indonesia, as a developing concessional starting in 1970-80s in line with the Postmodern Period, began to be developed in America. The thinking of Some legal experts in Indonesia who developed his thinking in the field of Legal Theory can found in the thought of Mochtar Kusumaatmadja and Satjipto Rahardjo who became the study this article.

Mochtar Kusumaatmadja as pioneers of the sect Unpad, best known for his development of the theory of law, has been used in the development of the law of Indonesia at the time of the new order. There are 2 (two) things that became the core of the legal theory of development developed by Mochtar Kusumaatmadja, i.e.:

a. Order or regularity in the renewal effort or that development is something that is desirable or even seen the absolute existence.

b. Law within the meaning of a rule or the rule of law can indeed serve as a regulator or a means of development in the sense of direction of the contracting activities of the desired community toward updates. This thought-provoking phrase adopted from the pioneers of Sociological Jurisprudence in the Americas, Rescoe Pound: the law is tools of social engineering. The difference, Sociological Jurisprudence has a judicial character by exploring the decisions of judges as the law to affirm race black marginal position in America. Whereas in the sect that stands out is the character served as legislation and administration are done through the instrument of legislation and the decisions of State agencies.

The sect Unpad also confirms the link between the law with politics as reflected in the famous Mochtar Kusumaatmadja expression "law without power is wishful thinking and power without law is tyranny";

Philosophically, the theory of law construction of Mochtar Kusumaatmadja was supported by the concepts of law and branches in the philosophy of law as follows: 
a. First, the flow law of nature pioneered by Plato, Aristotle, Thomas Aquinas, Grotius. The core of this is the law that applies to the universal and eternal.

b. Second, the flow of Postivisme Law which States that the law is the sovereign ruler command (John Austin) or is the will of the State (Hans Kelsen).

c. Third, schools of history, who was born in Germany and spearheaded by Carl von Savigny who claimed that the law was not made but rather grow and develop together with the community. This concept was influenced by religion (supernatural), as well as prevailing in Indonesia (influence history) with the enactment of the law is determined by the balance of "magis-religius (kosmis)."

d. Fourth, the flow of Sociological Jurisprudence was pioneered by Eugen Ehrlich (Germany), and developed in the United States (Roscoe Pound). The concept of the law States that laws are made to heed the law living in the community (living law) both written and unwritten.

e. Fifth, the flow of Pragmatic Legal Realism that was born in the United States was pioneered by Roscoe Pound. The concept of the ruling that the law can serve as a tool of the community renewal (law as a tool of social engineering).

f. Keenam, aliran Marxis Yurisprudence, yang dipelopori oleh Karl Marx, bahwa hukum harus memberi perlindungan kepada golongan proletar (golongan ekonomi lemah).

g. Seventh, Anthropoligical Jurisprudence was pioneered by Northorp and Mac Dougall. According to the law, Northorp reflects the social value of the culture, while according to Mac Dougall of the law contains the value system.

Related to the concept of law, Mochtar Kusumaatmadja stated that the law is not only complex rules and the principle of governing, but also covering the institutions and processes that are needed to bring about the enactment of the law in reality. The word "rule/principle" here refers to the ideal element in the legal system, the word "institution" refers to the operational elements, and the word "process" refers to the factual elements. Thus, the theory of law Development seeks to balance between positive law (law in the books) and the law of life (living law).

The function of the law is not directed solely as a means of social order (as a function of the most conservative of the law) but also as a means of social engineering. Thus, the law of compulsory direct on the achievement of public order as a condition to the certainty and fairness realized very diverse. In this case, Mochtar Kusumaatmadja has managed to find a legal concept in the sense of a dynamic that includes four elements above as a series that relate to one another and are always in a State of dynamic (moving). About national laws conducted development also are selective. These areas of the law which we recommend should develop or perfected, Mochtar Kusumaatmadja gives three (3) sizes as follows:

a. The measure needs urgently (urgent need) This measure is used when we are hard pressed to do so without selecting opportunity in the true sense immediately;

b. The size of the feasibility (business feasibility)

This measure used when we exposed to areas of law containing too much obstruction. To areas of law such as this need to be suspended and then selected the areas that there were no complications-complications of the cultural, religious and sociological;

c. The measure changes the subject matter (fundamental change)

In this case, the changes (through legislation) required because of political considerations, economic and/or social.

Along with the fascist new order, criticism arose against the opinion of Mochtar Kusumaatmadja.. Rikardo Simarmata stated the philosophy of law of development-oriented order and certainty of giving space to local community 
narrow to exaggerating values and symbols cultured. Exemplified Act No. 5 of the year 1979 the Village Government overhaul of the structure of local government for the uniformed village is one of the effects of Madzab and served In other words, need to be developed the methodology of drafting legislation or transformation in a participatory bottom up, not top down. Romli Atmasasmita by also expressed that Mochtar Kusumaatmadja was never explicitly mentioned the bureaucrats should be a Legal Theory in the construction of the motor, or never put it as the fourth element of the legal system. Romli Atmasasmita through Law Integration thoughts. The rate that the Legal Theory of development have yet to consider the political system, the system of bureaucracy, and the principles of "good governance" was not as big as the current echo in the bureaucracy. Therefore, Romli Atmasasmita believes that the development of the theory of law favors the role of law and ignore the role of the bureaucracy in the national development.

In the meantime, Satjipto Rahardjo departs from his distress with the State of the law in the way inaugural Indonesia raised the legal thinking about Progressive Law. He observed almost absolutely no breakthrough intelligent face the transition of the new order and a more concern not only legal run anymore as a mere routine but also mocked as merchandise. Therefore, Satjipto Rahardjo argued that the law should be viewed by theorists and practitioners of the law for man and not vice versa. The opinion is in line with the view of the law of critical (critical legal studies) that the law is not an institution off of human interests. Bad rules, should not be a hindrance for the perpetrators of the progressive law to bring justice to the people and seeker of Justice.

On the concept of a progressive law, the law does not serve for himself, but to reside outside of himself. The progressive law put the interests and needs of humanity or people as a point of orientation, so it must have sensitivity on issues arising in human relations. Even though the current law is also not solely devoted to human interests but even further towards the environment that becomes a human doing the rides of his life, as can be seen in the provisions of article 1 point 1 Act No. 32 of 2009 Year Protection and management of the environment, environmental concepts related with its translations on other articles.

The law also requires the progressive character of the presence of the law associated with the empowerment of the social goals that developed as Roscou pounds. The law also has Progressive thinking proximity to natural law theory, namely concern on what by Hans Kelsen called metayuridical who maintain justice as Crown law. Facing the contemporary condition in this postmodern era with a variety of issues that are full of complications, then law enforcement agencies prosecuted do steps breakthrough (discretion) in conducting enforcement and not just applying the regulations in legisme. Consequently, the process of change no longer centered on the rules, but on the perpetrators of the creativity, a law to actualize the law in time and space. The law offender repressive may make changes by doing a creative definition of the existing rules, without having to wait for the rule change. Therefore, the regulations are weak or ill should not be a barrier to the perpetrators of the progressive law to bring justice to the people and the seekers of Justice, because they can do against an interpretation of the regulation.

Contributions to the theory of Progressive Law found on the idea that the law is the behavior of the system (system of behavior). The three natures law system (norms, behaviors, and values) referred to by Romli with "the tripartite character of the Indonesian legal and bureaucratic theory of social engineering" in the thought of the progressive Law to developed for the benefit of manke. With the philosophy of the human be the deciding point of orientation law and law of serving humanity. Legal quality determined by its ability to serve on human wellbeing, so the law embraced the progressive "ideology" of pro-legal justice and the Law Prothe people. 


\section{Conclusion}

Theory of law emerging from centuries of the century not only shows color Cosmology and the spirit of his time, but also gave rise to a shift in the way legal historians point of view by the transitional period began the days of classical, modern, and thinkers of the age Postmodern (contemporary). The legal theory of the classical period colored the horizon religiosity, well sourced on the mystical religiosity as well as cosmology. The Modern theory of law based on the ability of logic, ability ratio, human thinking ability in determining the substance of the law, so what becomes law defined the man himself and the law be human-made. Meanwhile, in the Postmodern theory of law with the method deconstruction, law devoted for the sake of balance ratios and taste for the welfare of humanity and the environment resources and the human place run his life. The legal theory of development and the progressive theory of law developed by the Indonesia Law seeks a balance between positive law (law in the books) and the law of life (living law) by giving the centrality and/or development to one of the parties. The second thought that grows on the Postmodern era in fact as an attempt of the liberation of the thinking of the status quo, a collaboration of legal theories that developed earlier by adopting legal thoughts to suit your needs the community and the State of Indonesia who is engaged in the crossroads towards modernization. In that regard, the law should put forward conscience (conscience) are implemented through the law that established the legal authorities, officials of Justice, and the law that protects human beings and their environment life.

\section{Reference}

[1]Bernard L. Tanya, dkk., 2006, Teori Hukum Strategi Tertib Manusia Lintas Ruang Dan Generasi”, CV. Kita, Surabaya.

[2] J.M. Balkin, 1987, Deconstructive Practice and Legal Theory, Faculty Scholarship Series. Yale

[3].Khudzaifah Dimyati, 2004, Teorisasi Hukum: Studi tentang Perkembangan Pemikiran
Hukum di Indonesia 1945 - 1990. P Muhammadiyah University Press, Surakarta.

[4] Mochtar Kusumaatmadja, 1995, Hukum, Masyarakat, dan Pembinaan Hukum Nasional, Binacipta, Bandung.

[5] --------, 1986, Pembinaan Hukum Dalam Rangka Pembangunan Nasional, Binacipta, Bandung.

[6] Pusat Studi Hukum Kritis, 2005, 9 Jurus Merancang Peraturan untuk Transformasi Sosial, PSHK, Jakarta.

[7]Rikardo Simarmata, 2003, Pembaharuan Hukum Daerah, Menuju Pengembalian Hukum Kepada Rakyat: Buku Pegangan Bagi Pendamping Hukum Rakyat, YBH Bantaya, Yayasan Kemala dan Perkumpulan HuMa, Jakarta,

[8] Satjipto Rahardjo, 2010, Penegakan Hukum Progresif, Kompas, Jakarta.

[9] Sudikno Mertokusumo, 2012, Teori Hukum, Cahaya Atma Pustaka, Yogyakarta. 